\title{
Wholemeal Spelt Bread Enriched with Green Spelt as a Source of Valuable Nutrients
}

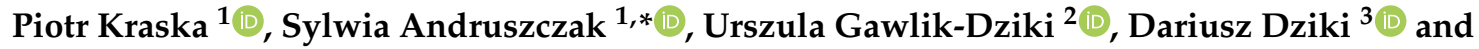 \\ Ewa Kwiecińska-Poppe ${ }^{1}$ D \\ 1 Department of Herbology and Plant Cultivation Techniques, University of Life Sciences, 20-950 Lublin, \\ Poland; piotr.kraska@up.lublin.pl (P.K.); ewa.kwiecinska@up.lublin.pl (E.K.-P.) \\ 2 Department of Biochemistry and Food Chemistry, University of Life Sciences, 20-704 Lublin, Poland; \\ urszula.gawlik@up.lublin.pl \\ 3 Department of Thermal Technology and Food Process Engineering, University of Life Sciences, \\ 20-612 Lublin, Poland; dariusz.dziki@up.lublin.pl \\ * Correspondence: sylwia.andruszczak@up.lublin.pl; Tel.: +48-814-456-687
}

Received: 25 February 2020; Accepted: 24 March 2020; Published: 27 March 2020

\begin{abstract}
The aim of this study was to evaluate the nutritional value of wholemeal bread prepared from the flour of spelt wheat (Triticum aestivum ssp. spelta) that was enriched by the addition of freeze-dried spelt grain (at proportions of $4 \%, 8 \%$, and $12 \%$, respectively, in relation to the flour weight). The spelt grain used in the study was harvested at the milk dough stage (the so-called green grain). Green spelt grain was characterized by a significantly higher content of minerals namely $\mathrm{P}, \mathrm{Mg}$, $\mathrm{Ca}$ and $\mathrm{Zn}$ compared to ripe spelt grain. Additionally, it contained significantly higher amounts of amino acids (Asp, Thr, Ser, Gly, Ala, Cys, Val, Met, Ile, Leu, Phe, Lys), lipids, as well as monounsaturated fatty acids (MUFA), and omega- 3 and omega- 9 acids. However, it had a lower content of palmitic, stearic, and linoleic acids, polyunsaturated fatty acids (PUFA), and omega-6 acids. The results showed that the nutritional value of bread was improved by the green spelt grain, however the $\omega 6 / \omega 3$ ratio in bread enriched with green spelt grain was slightly less favorable than in control bread. Among all the products tested, bread enriched with a $12 \%$ proportion of green spelt grain was characterized by the highest content of almost all the amino acids (except for Pro, Cys, and Met), as well as in $\mathrm{Mg}, \mathrm{Zn}, \mathrm{Mn}, \mathrm{Cu}$ and Fe. In addition, overall acceptability of this bread was the highest. Bread enriched with $8 \%$ of green grain contained the highest amount of $\mathrm{P}, \mathrm{Ca}$, Pro, linoleic acid, PUFA, and $\omega 6$ acids, while bread enriched with $4 \%$ of green spelt grain had the highest content of palmitic acid and saturated fatty acids.
\end{abstract}

Keywords: spelt wheat; green grain; bread; chemical composition

\section{Introduction}

Bakery products are commonly included in the daily diet of humans. Nowadays, consumers show increased interest in bread enriched with various ingredients [1]. These often include natural additives such as oats and bran as well as germs [2-4]. A number of lifestyle diseases are known to be caused by the consumption of an inappropriate diet. Moreover, modern food is too often highly processed, while bakery products with a predominance of white flour are mostly poor in health-promoting substances such as phenolic compounds, fiber, or vitamins [5]. Fortunately, fruit and seed coat are a valuable source of these substances, and thus, in recent years, consumption of wholegrain cereal products has been emphasized. Nonetheless, due to the application of heavy metals or pesticides in conventional farming, seed coat may also harbor these undesired substances [6,7]. Therefore, grain produced through organic farming is particularly sought for the production of baked products. 
Currently, traditional species that were grown in the past are regaining popularity [8]. One among them is spelt wheat (Triticum aestivum ssp. spelta), which is one of the oldest grown cereals in the world. Spelt grain contains many valuable nutrients that are of importance in the human diet. Compared to common wheat, spelt consists of higher amounts of proteins, dietary fiber, unsaturated fatty acids, amino acids, and vitamins (A, D, and E) [9-12]. Furthermore, spelt is a rich source of minerals [13,14] and constituents exhibiting important biological activities, such as antioxidants [15-17]. According to nutritional experts, spelt products can be a valuable dietary supplement and, therefore, regular intake of meals containing processed spelt grain can have a beneficial effect on human health, by preventing many life-threatening diseases [18]. It has also been proven that systematic consumption of spelt wheat regenerates the entire body, increases its resistance potential, promotes the reduction in blood cholesterol, and supports the digestive functions [19].

An important attribute of spelt is that its grain can be harvested and used at different maturity stages. For instance, spelt grain harvested at the milk dough stage (green grain) has several nutrients, but the percentage of starch is less. However, when dried immediately after harvest and subsequently dehulled, the grain is known to possess a high content of protein and mineral salts. It can serve as an excellent additive to bakery products, which enhances their taste and nutritional qualities [20]. Such types of enriched products, especially low-processed food, are in huge demand in the food market [21].

The research hypothesis assumes that bread enriched with unripe spelt grain has improved properties as compared to bread baked from flour obtained from ripe spelt grain. The idea behind the formulation of new recipes for baking bread is very well in agreement with the recent preference of consumers for food products with specific health-enhancing qualities. Thus far, such a kind of baked products has not been analyzed by any authors. Therefore, the aim of this study was to evaluate the chemical composition of spelt bread enriched with green grain harvested at the milk dough stage, which was added at different proportions to the flour. In addition, the chemical composition of the baking ingredients used was determined. Cereal grain used in the study was produced through organic farming.

\section{Materials and Methods}

The study material was spelt grain harvested in 2017 at the milk dough stage (the so-called green grain), which is used as an additive to wholemeal bakery products made from spelt flour. The ingredients used to prepare bread samples were obtained from the Organic Farm belonging to the Agricultural Advisory Center in Brwinów, Radom Branch (Chwałowice, Poland). The spelt grain was ground to wholemeal flour using SM 200 cutting mill (Retsch, Haan, Germany). The screen undersize sifted through a $0.350 \mathrm{~mm}$ mesh screen was considered to be wholemeal flour. The screen oversize was sent back for grinding.

In order to obtain green spelt, the grain was harvested at the milk dough stage (in the middle of June). This process involved the collection of whole ears, which were then freeze dried at $20{ }^{\circ} \mathrm{C}$ and under a pressure of $52 \mathrm{~Pa}$, using a freeze drier according to the procedure described by Biernacka et al. [22] (Figure 1). In the next step, the grain obtained from the dried ears was threshed. Green spelt grain was added in the amounts of $4 \%, 8 \%$, and $12 \%$ of the total flour content (Figure 2). Each bread sample was prepared in three replicates, according to the method described by Romankiewicz et al. [23]. The quality of the obtained spelt grain (harvested at the maturity stage and milk dough stage) was determined by commonly used analytical procedures [24]: the content of total protein (through mineralization using sulfuric acid followed by determination using the Kjeldahl distillation method and titration detection); $\mathrm{N}$ (mineralization in sulfuric acid and oxygenated water; determination by the Kjeldahl distillation method; titration detection), P (mineralization in sulfuric acid and oxygenated water; determination by vanadium-molybdate spectrophotometric method; Spekol spectrophotometer (Carl Zeiss AG, Oberkochen, Germany), K and Ca (mineralization in sulfuric acid and oxygenated water; determination by flame photometry; PEP7 photometer (Jenway, 
Staffordshire, UK)), Mg (mineralization in sulfuric acid and oxygenated water; determination by atomic absorption spectrometry; Perkin-Elmer spectrometer), $\mathrm{Cu}, \mathrm{Zn}, \mathrm{Mn}, \mathrm{Fe}$ (mineralization in perchloric and nitric acids (1:4); determination by atomic absorption spectrometry; Avanta spectrometer (GBC Scientific Equipment, Australia), according to PN-EN 14084:2004), Na (determination by atomic absorption spectrometry), B (mineralization with $\mathrm{Ca}(\mathrm{OH})_{2}$ in a furnace; determination by spectrophotometric curcumin method; Spekol spectrophotometer), lipids content (Soxhlet method), fatty acid composition (gas chromatography-PN-ISO 5509; Varian 450-GC gas chromatograph (Agilent Technologies, Santa Clara, CA, USA), and amino acid composition (ion exchange chromatography, AAA 500 amino acid analyzer (INGOS, K Nouzovu, Czech Republic).

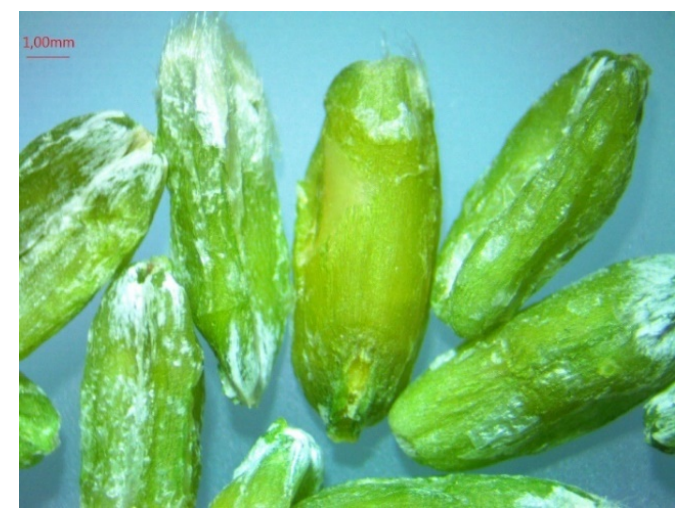

Figure 1. Picture of spelt grain harvested at milk dough stage after freeze-drying (green spelt grain).

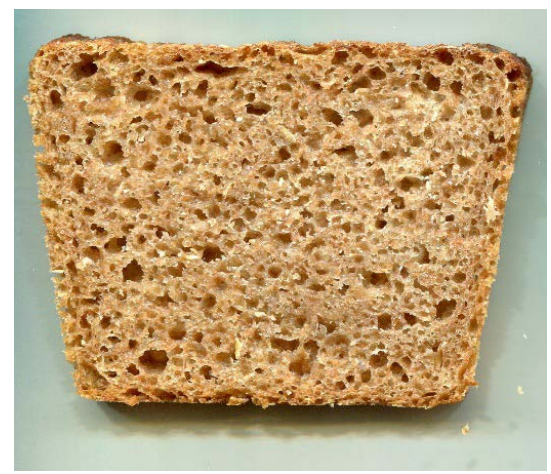

(a)

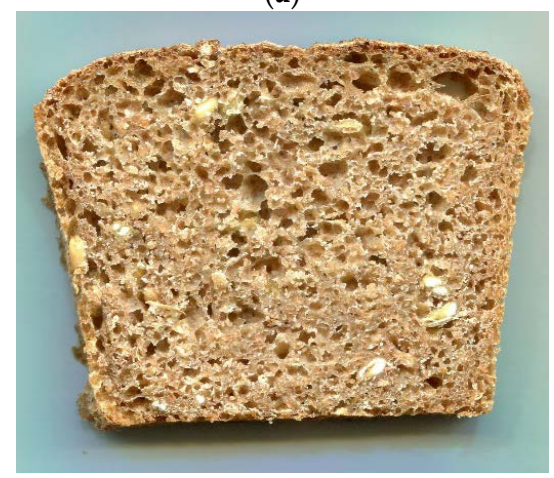

(c)

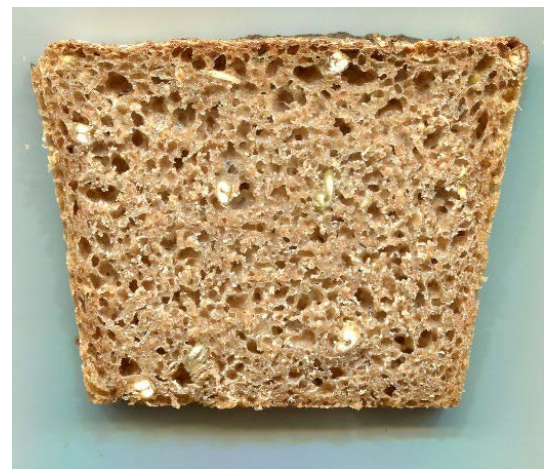

(b)

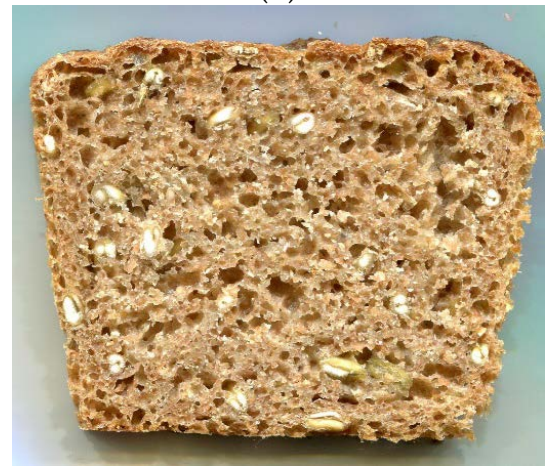

(d)

Figure 2. Wholemeal bakery products made from spelt flour: (a) Control bread; (b) Spelt bread enriched with green grain of spelt added in proportion of $4 \%$; (c) Spelt bread enriched with green grain of spelt added in proportion of $8 \%$; (d) Spelt bread enriched with green grain of spelt added in proportion of $12 \%$. 
Similarly, the quality of the prepared bread was also determined by analyzing the content of macro- and micronutrients, as well as the composition of amino acids and fatty acids. Each sample was measured in triplicate. The chemical analyzes were carried out in an accredited laboratory (accreditation certificate No. AB 1375 issued by the Polish Centre for Accreditation), which meets the requirements of the PN-EN ISO/IEC 17025:2005 standard. Moreover, the preliminary sensory evaluation (overall acceptability) of obtained bread samples was performed on a nine-point hedonic scale [25]. Overall acceptability of breads was determined on the fresh breads (five hours after baking) by 34 untrained panelists commonly consuming wheat bread.

All the tests were performed in triplicate. The results obtained were statistically analyzed by the analysis of variance using Statistica PL 13.3 (TIBCO Software Inc., Tulsa, OK, USA). The means were compared using Tukey's least significant difference test $(p \leq 0.05)$.

\section{Results and Discussion}

\subsection{Content of Protein and Some Elements}

Total content of protein and minerals is an important characteristic that determines the consumer preference and the nutritional value of raw material. The results showed that the total protein and nitrogen contents of the green grain of spelt were slightly higher than that of the spelt grain harvested at the fully ripe stage, but the differences were not significant (Table 1). By contrast, Kraska et al. [20] observed a distinctly higher content of nitrogen in the spring spelt wheat cultivar 'Wirtas' harvested at the fully ripe stage compared to the spring spelt harvested at the milk dough stage. Andruszczak [26] found that the total protein content in spelt grain ranged between $14.1 \%$ and $17.4 \%$ depending on the cultivar. However, in that study spelt wheat was grown under conventional farming conditions, where production-enhancing agents used in industries were applied.

Table 1. The content of protein and macroelements in the grain of spelt.

\begin{tabular}{ccccccc}
\hline Grain & $\begin{array}{c}\text { Protein } \\
\mathbf{\%}\end{array}$ & $\begin{array}{c}\mathbf{N} \\
\mathbf{g ~ k g}\end{array}$ & $\begin{array}{c}\mathbf{P} \\
\mathbf{g ~ k g}\end{array}$ & $\begin{array}{c}\mathbf{K} \\
\mathbf{g ~ k g}\end{array}$ & $\begin{array}{c}\mathbf{M g} \\
\mathbf{g ~ k g}\end{array}$ & $\begin{array}{c}\text { Ca } \\
\mathbf{~ m g ~ k g}^{-\mathbf{1}}\end{array}$ \\
\hline Ripe spelt grain & $10.75 \pm 0.54 \mathrm{a}^{1}$ & $17.20 \pm 0.85 \mathrm{a}$ & $3.83 \pm 0.17 \mathrm{a}$ & $3.99 \pm 0.19 \mathrm{a}$ & $1.040 \pm 0.02 \mathrm{a}$ & $187.0 \pm 1.9 \mathrm{a}$ \\
Green spelt grain & $12.38 \pm 0.61 \mathrm{a}$ & $19.80 \pm 0.91 \mathrm{a}$ & $4.17 \pm 0.12 \mathrm{~b}$ & $4.05 \pm 0.12 \mathrm{a}$ & $1.253 \pm 0.06 \mathrm{~b}$ & $260.0 \pm 7.8 \mathrm{~b}$ \\
\hline
\end{tabular}

${ }^{1}$ Different letter $(\mathrm{a}, \mathrm{b})$ in the same column indicate statistically significant difference between means $(p \leq 0.05)$.

The content of $\mathrm{P}$ was observed to be significantly higher in the spelt grain harvested at the milk dough stage, compared to the ripe spelt grain. A similar relationship was found for the content of $\mathrm{Mg}$ and $\mathrm{Ca}$. However, the date of harvesting did not significantly affect the $\mathrm{K}$ content in spelt grain. This was in accordance with the results of other authors $[13,26]$ who noted a similar content of macronutrients in ripe spelt grain and green grain.

Green spelt grain was also determined to have a significantly higher content of Zn $(>20.7 \%)$ compared to the spelt grain harvested at the fully ripe stage (Table 2). Moreover, unripe grain was found to exhibit a slightly higher content of $\mathrm{Mn}, \mathrm{Fe}, \mathrm{B}$, and $\mathrm{Na}$ in comparison with the ripe spelt grain. It was found that the spelt harvested at the milk dough stage was characterized by a lower Cu content, but these differences were shown to be insignificant by statistical analysis. The contents of $\mathrm{Zn}$ and $\mathrm{Cu}$ estimated in spelt grain did not substantially differ from the values reported by Wojtkowiak and Stępień [27]. However, these authors demonstrated a much higher content of Mn (40.4-46.4 mg kg-1) and Fe (58.1-70.5 $\left.\mathrm{mg} \mathrm{kg}^{-1}\right)$ in spelt grain. Wanic et al. [28] also reported a similar content of Zn in spelt grain, a lower content of $\mathrm{Cu}\left(2.2 \mathrm{mg} \mathrm{kg}^{-1}\right)$, and a higher content of $\mathrm{Mn}$ and Fe (32.7 and $75.6 \mathrm{mg} \mathrm{kg}^{-1}$, respectively) in their study. 
Table 2. The content of selected microelements in the grain of spelt.

\begin{tabular}{ccccccc}
\hline Grain & $\begin{array}{c}\mathbf{Z n} \\
\mathbf{m g ~ k g}^{-1}\end{array}$ & $\begin{array}{c}\mathbf{M n} \\
\mathbf{m g ~ k g}\end{array}$ & $\begin{array}{c}\mathbf{C u} \\
\mathbf{m g ~ k g}\end{array}$ & $\begin{array}{c}\mathbf{F e} \\
\mathbf{m g ~ k g}^{-\mathbf{1}}\end{array}$ & $\begin{array}{c}\mathbf{B} \\
\mathbf{m g ~ k g}^{-\mathbf{1}}\end{array}$ & $\begin{array}{c}\mathbf{~ N a} \\
\mathbf{g ~ k g}^{-\mathbf{1}}\end{array}$ \\
\hline Ripe spelt grain & $25.70 \pm 1.25 \mathrm{a}^{\mathbf{1}}$ & $19.03 \pm 0.91 \mathrm{a}$ & $5.38 \pm 0.26 \mathrm{a}$ & $36.83 \pm 1.83 \mathrm{a}$ & $3.40 \pm 0.06 \mathrm{a}$ & $17.90 \pm 0.20 \mathrm{a}$ \\
Green spelt grain & $31.03 \pm 1.51 \mathrm{~b}$ & $20.93 \pm 1.04 \mathrm{a}$ & $3.81 \pm 0.11 \mathrm{a}$ & $49.23 \pm 1.47 \mathrm{a}$ & $4.69 \pm 0.23 \mathrm{a}$ & $25.73 \pm 0.76 \mathrm{a}$ \\
\hline
\end{tabular}

${ }^{1}$ Different letter $(\mathrm{a}, \mathrm{b})$ in the same column indicate statistically significant difference between means $(p \leq 0.05)$.

The total protein content in bread prepared from spelt flour enriched with $4 \%, 8 \%$ and $12 \%$ of green spelt grain was not found to vary significantly (Table 3). However, bread enriched with unripe grain showed a slightly higher content of protein compared to the control bread. A similar relationship was found for the content of nitrogen and magnesium. In a study on various components of bread, Litwinek et al. [29] found the highest total protein content in bread made from spelt flour, a medium content in bread from wheat flour, and the lowest content in bread from rye wholemeal (50-fold lower compared to spelt bread).

Table 3. The content of protein and macroelements in control bread and enriched breads.

\begin{tabular}{ccccccc}
\hline $\begin{array}{c}\text { Type of } \\
\text { Bread }\end{array}$ & $\begin{array}{c}\text { Protein } \\
\mathbf{\%}\end{array}$ & $\begin{array}{c}\mathbf{N} \\
\mathbf{g ~ k g}\end{array}$ & $\begin{array}{c}\mathbf{P} \\
\mathbf{g ~ k g}\end{array}$ & $\begin{array}{c}\mathbf{K} \\
\mathbf{g ~ k g}\end{array}$ & $\begin{array}{c}\mathbf{M g} \\
\mathbf{g ~ k g}^{-\mathbf{1}}\end{array}$ & $\begin{array}{c}\mathbf{C a} \\
\mathbf{m g ~ k g}\end{array}$ \\
\hline CB $^{1}$ & $11.81 \pm 0.57 \mathrm{a}$ & $18.90 \pm 0.96 \mathrm{a}$ & $3.73 \pm 0.18 \mathrm{a}$ & $3.79 \pm 0.18 \mathrm{a}$ & $1.037 \pm 0.02 \mathrm{a}$ & $284.33 \pm 3.84 \mathrm{a}$ \\
BGS4 & $12.13 \pm 0.60 \mathrm{a}$ & $19.40 \pm 0.96 \mathrm{a}$ & $3.70 \pm 0.11 \mathrm{a}$ & $3.28 \pm 0.09 \mathrm{a}$ & $1.057 \pm 0.05 \mathrm{a}$ & $267.00 \pm 6.01 \mathrm{a}$ \\
BGS8 & $12.13 \pm 0.47 \mathrm{a}$ & $19.40 \pm 0.97 \mathrm{a}$ & $3.87 \pm 0.07 \mathrm{~b}$ & $2.98 \pm 0.15 \mathrm{a}$ & $1.053 \pm 0.04 \mathrm{a}$ & $294.33 \pm 8.82 \mathrm{a}$ \\
BGS12 & $11.94 \pm 0.41 \mathrm{a}$ & $19.10 \pm 0.94 \mathrm{a}$ & $3.81 \pm 0.19 \mathrm{ab}$ & $2.84 \pm 0.08 \mathrm{a}$ & $1.083 \pm 0.05 \mathrm{a}$ & $265.33 \pm 9.91 \mathrm{a}$ \\
\hline
\end{tabular}

${ }^{1}$ CB - control bread; BGS4—bread enriched with $4 \%$ of green spelt grain; BGS8-bread enriched with $8 \%$ of green spelt grain; BGS12 - bread enriched with $12 \%$ of green spelt grain; Different letter $(a, b)$ in the same column indicate statistically significant difference between means $(p \leq 0.05)$.

Bread with an $8 \%$ proportion of green spelt grain (BGS8) was characterized by the highest content of P. The content of phosphorus in the control bread (CB) and bread enriched with $4 \%$ of unripe spelt grain (BGS4) was found to be significantly lower by $3.6 \%$ and $4.4 \%$, respectively. The lowest K content was observed in bread made from spelt flour enriched with $8 \%$ and $12 \%$ proportion of green spelt grain, but compared to the CB and BGS4 the differences were not significant. The Ca content did not differ significantly in all the bread samples, with the highest amount of this element found in bread prepared from flour added with $8 \%$ green spelt grain, while the least in bread enriched with green grain at the proportion of $12 \%$ (BGS12).

The $\mathrm{Zn}$ content in the bread samples did not differ significantly (Table 4). However, a slightly higher content of this element was noted in bread with green spelt grain compared to the control bread. A similar relationship was found for $\mathrm{Na}$ content. The Mn content determined in CB was significantly lower compared to all the other bread samples. In addition, BGS4 contained significantly less Mn compared to BGS12.

Table 4. The content of selected microelements in control bread and enriched breads.

\begin{tabular}{|c|c|c|c|c|c|c|}
\hline $\begin{array}{c}\text { Type of } \\
\text { Bread }\end{array}$ & $\underset{\mathrm{Zn}}{\mathrm{Zn} \mathrm{kg}}$ & $\begin{array}{c}\mathrm{Mn} \\
\mathrm{mg} \mathrm{kg}^{-1}\end{array}$ & $\begin{array}{c}\mathrm{Cu} \\
\mathrm{mg} \mathrm{kg}^{-1}\end{array}$ & $\begin{array}{c}\mathrm{Fe} \\
\mathrm{mg} \mathrm{kg}^{-1}\end{array}$ & $\begin{array}{c}\text { B } \\
\mathrm{mg} \mathrm{kg}^{-1}\end{array}$ & $\begin{array}{c}\mathrm{Na} \\
\mathrm{g} \mathrm{kg}^{-1}\end{array}$ \\
\hline $\mathrm{CB}^{1}$ & $27.53 \pm 1.37 \mathrm{a}$ & $15.73 \pm 0.78 \mathrm{a}$ & $4.40 \pm 0.22 \mathrm{a}$ & $37.40 \pm 1.87 \mathrm{a}$ & $5.83 \pm 0.19 a$ & $8.38 \pm 0.28 \mathrm{a}$ \\
\hline BGS4 & $28.20 \pm 1.41 \mathrm{a}$ & $17.83 \pm 0.87 b$ & $3.54 \pm 0.11 \mathrm{a}$ & $32.73 \pm 0.98 a$ & $2.67 \pm 0.13 b$ & $10.14 \pm 0.26 \mathrm{a}$ \\
\hline BGS8 & $28.30 \pm 1.33 \mathrm{a}$ & $18.23 \pm 0.91 b c$ & $4.60 \pm 0.09 \mathrm{a}$ & $35.73 \pm 1.78 \mathrm{a}$ & $3.18 \pm 0.12 c$ & $9.15 \pm 0.27 \mathrm{a}$ \\
\hline BGS12 & $28.90 \pm 1.41 \mathrm{a}$ & $19.57 \pm 0.94 \mathrm{c}$ & $4.83 \pm 0.24 \mathrm{a}$ & $42.27 \pm 0.84 a$ & $3.46 \pm 0.17 \mathrm{~d}$ & $9.30 \pm 0.37 \mathrm{a}$ \\
\hline
\end{tabular}

${ }^{1}$ CB—control bread; BGS4-bread enriched with $4 \%$ of green spelt grain; BGS8-bread enriched with $8 \%$ of green spelt grain; BGS12 - bread enriched with $12 \%$ of green spelt grain; Different letter (a, b, c, d) in the same column indicate statistically significant difference between means $(p \leq 0.05)$.

The lowest amount of $\mathrm{Cu}$ and Fe was found in BGS4, while the highest contents were found in BGS12. However, in all bread samples evaluated, the contents of these elements were within the 
margin of statistical error. By contrast, bread enriched with green spelt grain was characterized by a significantly lower B content compared to control bread. The obtained results thus prove that spelt is a valuable source of nutrients and can be successfully included in the human diet. This is also supported by the results of Litwinek et al. [29]. The authors reported a higher content of $\mathrm{P}, \mathrm{K}, \mathrm{Mg}, \mathrm{Ca}, \mathrm{Cu}$, and Fe in bread made from spelt flour compared to bread made from common wheat flour. At the same time, they indicated a higher content of $\mathrm{Mn}$ and $\mathrm{Zn}$ in spelt flour bread. Grembecka et al. [30] demonstrated that the different baked products investigated in their study, in particular crisp and dark baked ones, had a high amount of magnesium, phosphorus, zinc and iron and thus they can be included as a source of nutrients in the daily diet of humans.

\subsection{Amino Acid Composition}

The nutritional value of protein is largely determined by the composition of amino acids. Waga et al. [31] found that spelt wheat was characterized by a significantly higher content (20-60\%) of almost all amino acids than common wheat grain. In our study, the green spelt grain was found with a significantly higher content of Asp, Thr, Ser, Gly, Ala, Cys, Val, Met, Ile, Leu, Phe, Lys, and Trp, compared to spelt grain harvested at the fully ripe stage (Table 5). In turn, unripe spelt grain harvested at the milk dough stage contained a significantly lower amount of Glu and Pro. Furthermore, the present study confirmed the relationship indicated by Kraska et al. [20] in their study, in which the content of the essential amino acids Lys and Met as well as that of the nonessential amino acid Ala was shown to be higher in green grain compared to the spelt grain harvested at the fully ripe stage. Andruszczak [26] also reported a similar amino acid composition in spelt grain.

Table 5. The content of amino acids in spelt grain $\left[\mathrm{mg} \mathrm{g}^{-1}\right]$.

\begin{tabular}{ccc}
\hline \multirow{2}{*}{ Amino Acid } & \multicolumn{2}{c}{ Grain } \\
\cline { 2 - 3 } & Ripe Spelt Grain & Green Spelt Grain \\
\hline Asp & $5.78 \pm 0.29 \mathrm{a}^{1}$ & $6.73 \pm 0.34 \mathrm{~b}$ \\
Thr & $2.85 \pm 0.14 \mathrm{a}$ & $3.24 \pm 0.10 \mathrm{~b}$ \\
Ser & $4.53 \pm 0.14 \mathrm{a}$ & $4.75 \pm 0.24 \mathrm{~b}$ \\
Glu & $34.2 \pm 1.37 \mathrm{a}$ & $33.8 \pm 1.68 \mathrm{~b}$ \\
Pro & $11.4 \pm 0.57 \mathrm{a}$ & $10.9 \pm 0.44 \mathrm{~b}$ \\
Gly & $4.00 \pm 0.08 \mathrm{a}$ & $4.33 \pm 0.09 \mathrm{~b}$ \\
Ala & $3.54 \pm 0.14 \mathrm{a}$ & $4.77 \pm 0.24 \mathrm{~b}$ \\
Cys & $2.62 \pm 0.13 \mathrm{a}$ & $3.71 \pm 0.11 \mathrm{~b}$ \\
Val & $4.77 \pm 0.24 \mathrm{a}$ & $5.35 \pm 0.27 \mathrm{~b}$ \\
Met & $2.18 \pm 0.98 \mathrm{a}$ & $2.65 \pm 0.13 \mathrm{~b}$ \\
Ile & $3.38 \pm 0.10 \mathrm{a}$ & $3.89 \pm 0.16 \mathrm{~b}$ \\
Leu & $7.13 \pm 0.36 \mathrm{a}$ & $7.74 \pm 0.39 \mathrm{~b}$ \\
Tyr & $2.60 \pm 0.13 \mathrm{a}$ & $2.52 \pm 0.13 \mathrm{a}$ \\
Phe & $4.96 \pm 0.15 \mathrm{a}$ & $6.01 \pm 0.12 \mathrm{~b}$ \\
His & $2.54 \pm 0.13 \mathrm{a}$ & $2.59 \pm 0.13 \mathrm{a}$ \\
Lys & $2.68 \pm 0.13 \mathrm{a}$ & $3.44 \pm 0.17 \mathrm{~b}$ \\
Arg & $4.40 \pm 0.13 \mathrm{a}$ & $4.50 \pm 0.10 \mathrm{a}$ \\
Trp & $1.42 \pm 0.07 \mathrm{a}$ & $4.18 \pm 0.21 \mathrm{~b}$ \\
\hline
\end{tabular}

${ }^{1}$ Different letter $(a, b)$ in the same row indicate statistically significant difference between means $(p \leq 0.05)$.

The highest Asp content was identified in bread with $12 \%$ addition of green spelt grain among all the bread samples evaluated (Table 6). Thr content did not vary significantly among the samples but a slightly higher content of this amino acid was only found in all enriched bread samples containing green spelt grain compared to the control. 
Table 6. The content of amino acids in control bread and breads enriched with green spelt grain, oat grain and sprouted lentil seeds $\left[\mathrm{mg} \mathrm{g}^{-1}\right]$.

\begin{tabular}{ccccc}
\hline \multirow{2}{*}{ Amino Acid } & \multicolumn{4}{c}{ Type of Bread } \\
\cline { 2 - 5 } & CB ${ }^{\mathbf{1}}$ & BGS4 & BGS8 & BGS12 \\
\hline Asp & $4.87 \pm 0.24 \mathrm{a}$ & $4.84 \pm 0.24 \mathrm{a}$ & $5.08 \pm 0.25 \mathrm{~b}$ & $5.29 \pm 0.26 \mathrm{c}$ \\
Thr & $2.88 \pm 0.14 \mathrm{a}$ & $2.95 \pm 0.09 \mathrm{a}$ & $2.94 \pm 0.15 \mathrm{a}$ & $3.00 \pm 0.09 \mathrm{a}$ \\
Ser & $4.90 \pm 0.15 \mathrm{a}$ & $4.84 \pm 0.24 \mathrm{a}$ & $5.10 \pm 0.15 \mathrm{~b}$ & $5.21 \pm 0.26 \mathrm{~b}$ \\
Glu & $33.4 \pm 1.34 \mathrm{a}$ & $34.3 \pm 1.72 \mathrm{~b}$ & $23.2 \pm 0.93 \mathrm{c}$ & $34.3 \pm 1.72 \mathrm{~b}$ \\
Pro & $11.0 \pm 0.55 \mathrm{a}$ & $11.10 \pm 0.44 \mathrm{a}$ & $10.30 \pm 0.52 \mathrm{~b}$ & $11.0 \pm 0.44 \mathrm{a}$ \\
Gly & $3.79 \pm 0.08 \mathrm{a}$ & $3.86 \pm 0.08 \mathrm{ab}$ & $3.80 \pm 0.08 \mathrm{a}$ & $3.96 \pm 0.08 \mathrm{~b}$ \\
Ala & $3.43 \pm 0.14 \mathrm{a}$ & $3.57 \pm 0.18 \mathrm{~b}$ & $3.48 \pm 0.14 \mathrm{ab}$ & $3.73 \pm 0.19 \mathrm{c}$ \\
Cys & $3.83 \pm 0.19 \mathrm{a}$ & $1.41 \pm 0.04 \mathrm{~b}$ & $1.15 \pm 0.06 \mathrm{c}$ & $1.27 \pm 0.04 \mathrm{~d}$ \\
Val & $4.64 \pm 0.23 \mathrm{a}$ & $4.84 \pm 0.24 \mathrm{~b}$ & $4.59 \pm 0.23 \mathrm{a}$ & $4.95 \pm 0.25 \mathrm{~b}$ \\
Met & $1.76 \pm 0.79 \mathrm{a}$ & $1.10 \pm 0.06 \mathrm{~b}$ & $1.10 \pm 0.50 \mathrm{~b}$ & $1.00 \pm 0.05 \mathrm{c}$ \\
Ile & $3.39 \pm 0.10 \mathrm{ab}$ & $3.52 \pm 0.14 \mathrm{a}$ & $3.31 \pm 0.10 \mathrm{~b}$ & $3.67 \pm 0.15 \mathrm{c}$ \\
Leu & $6.85 \pm 0.34 \mathrm{a}$ & $7.06 \pm 0.35 \mathrm{~b}$ & $6.78 \pm 0.34 \mathrm{a}$ & $7.07 \pm 0.35 \mathrm{~b}$ \\
Tyr & $1.69 \pm 0.08 \mathrm{a}$ & $1.71 \pm 0.09 \mathrm{a}$ & $1.62 \pm 0.08 \mathrm{a}$ & $1.73 \pm 0.09 \mathrm{a}$ \\
Phe & $4.81 \pm 0.14 \mathrm{a}$ & $5.03 \pm 0.10 \mathrm{~b}$ & $4.84 \pm 0.15 \mathrm{a}$ & $5.19 \pm 0.10 \mathrm{c}$ \\
His & $2.43 \pm 0.12 \mathrm{a}$ & $2.55 \pm 0.13 \mathrm{~b}$ & $2.42 \pm 0.12 \mathrm{a}$ & $2.58 \pm 0.13 \mathrm{~b}$ \\
Lys & $2.60 \pm 0.13 \mathrm{a}$ & $2.74 \pm 0.14 \mathrm{~b}$ & $2.60 \pm 0.13 \mathrm{a}$ & $2.81 \pm 0.14 \mathrm{~b}$ \\
Arg & $3.74 \pm 0.11 \mathrm{a}$ & $3.94 \pm 0.08 \mathrm{~b}$ & $3.79 \pm 0.11 \mathrm{a}$ & $4.04 \pm 0.08 \mathrm{c}$ \\
Trp & $1.41 \pm 0.07 \mathrm{a}$ & $1.25 \pm 0.06 \mathrm{~b}$ & $1.86 \pm 0.09 \mathrm{c}$ & $2.97 \pm 0.15 \mathrm{~d}$ \\
\hline
\end{tabular}

${ }^{1} \mathrm{CB}$ - control bread; BGS4-bread enriched with $4 \%$ of green spelt grain; BGS8 - bread enriched with $8 \%$ of green spelt grain; BGS12-bread enriched with $12 \%$ of green spelt grain; Different letter (a, b, c, d) in the same row indicate statistically significant difference between means $(p \leq 0.05)$.

Bread containing $4 \%$ of green spelt grain and control bread were characterized by a significantly lower content of Ser than BGS8 and BGS12. On the other hand, the content of Glu and Pro was found to be the lowest in the bread with $8 \%$ of green spelt grain. The Gly content determined in BGS12 was significantly higher than in the control bread as well as in bread with $8 \%$ of unripe spelt grain. The Ala content in the control bread was significantly lower than in all other bread samples, except for bread with $8 \%$ of green spelt grain, and it is worth noting that the highest Ala content was observed in BGS12. The highest content of Cys and Met was determined in the control bread made from spelt wheat flour, while the content of Val, Ile and Leu was highest in bread with $12 \%$ of green spelt grain. Bread with a $12 \%$ proportion of green spelt grain was characterized by a significantly higher content of Phe, Arg, and Trp compared to all other types of bread. By contrast, the content of Phe, Lys, and Arg in the control bread was significantly lower than in BGS4 and BGS12. At the same time, bread with $4 \%$ and $12 \%$ of green grain contained higher amount of His than CB and BGS8. The chemical composition of bread enriched with green grain of spelt is difficult to evaluate, and no studies on this subject can be found in the available literature. According to the results of the present study, bread enriched with green spelt grain can be included in the human diet and it can beneficial to expand the assortment of health-enhancing bakery products.

\subsection{Lipids Content and Fatty Acids Composition}

Spelt grain harvested at the milk dough stage was found to have a higher lipids content than spelt grain harvested at the fully ripe stage (Table 7). Kraska et al. [20] also observed a higher lipids content in unripe spelt grain than in grain harvested at the fully ripe stage. Moreover, they found that green spelt grain was characterized by a higher content of biologically active substances (phenolic acids, hydroxy acids), which determine the health-enhancing properties of a product. Escarnot et al. [10] reported a higher lipids content in spelt grain $(2.2-2.5 \% \mathrm{DM})$ than that estimated in the present study. Similarly, Sulewska et al. [32] found that the lipids content in spelt grain ranged from $2.33 \%$ to $2.38 \%$, depending on the cultivar of spelt wheat, which was similar to that observed in green grain in the present study. 
Table 7. Lipid content [\%] and the fatty acids profile [\%] in spelt grain.

\begin{tabular}{ccc}
\hline \multirow{2}{*}{$\begin{array}{c}\text { Lipid Content } \\
\text { and Fatty Acids Profile }\end{array}$} & Grain \\
\cline { 2 - 3 } & Ripe Spelt Grain & Green Spelt Grain \\
\hline Lipid content & $1.23 \pm 0.06 \mathrm{a}$ & $2.35 \pm 0.12 \mathrm{~b}$ \\
$16: 0^{1}$ & $16.63 \pm 0.83 \mathrm{a}$ & $14.68 \pm 0.44 \mathrm{~b}$ \\
$18: 0$ & $1.42 \pm 0.04 \mathrm{a}$ & $1.36 \pm 0.07 \mathrm{~b}$ \\
$18: 1 \mathrm{c} 9$ & $20.44 \pm 0.82 \mathrm{a}$ & $27.38 \pm 1.37 \mathrm{~b}$ \\
$18: 2$ c9, c12 & $55.01 \pm 2.75 \mathrm{a}$ & $47.62 \pm 1.90 \mathrm{~b}$ \\
$18: 3$ c9, c12, c15 & $2.92 \pm 0.06 \mathrm{a}$ & $6.03 \pm 0.12 \mathrm{~b}$ \\
SFA & $19.71 \pm 0.79 \mathrm{a}$ & $17.27 \pm 0.86 \mathrm{~b}$ \\
MUFA & $21.61 \pm 1.08 \mathrm{a}$ & $28.79 \pm 0.86 \mathrm{~b}$ \\
PUFA & $58.51 \pm 2.93 \mathrm{a}$ & $53.79 \pm 2.69 \mathrm{~b}$ \\
$\omega 3$ & $2.92 \pm 1.31 \mathrm{a}$ & $6.03 \pm 0.30 \mathrm{~b}$ \\
$\omega 6$ & $55.60 \pm 1.67 \mathrm{a}$ & $47.75 \pm 1.91 \mathrm{~b}$ \\
$\omega 9$ & $21.26 \pm 1.06 \mathrm{a}$ & $28.48 \pm 1.42 \mathrm{~b}$ \\
$\omega 6 / \omega 3$ & $19.04 \pm 0.57 \mathrm{a}$ & $7.92 \pm 0.31 \mathrm{~b}$ \\
\hline
\end{tabular}

1 16:0—palmitic acid; 18:0—-stearic acid; $18: 1$ c9-oleic acid; $18: 2$ c9, c12—linoleic acid; 18:3 c9, c12, c15— $\alpha$ linolenic acid; SFA-Saturated fatty acid; MUFA-Monounsaturated fatty acid; PUFA-Polyunsaturated fatty acid; $\omega$ 3-omega-3 PUFA; $\omega$ 6-omega-6 PUFA; $\omega$ 9-omega-9 PUFA; Different letter $(a, b)$ in the same row indicate statistically significant difference between means $(p \leq 0.05)$.

The content of palmitic and stearic acid was significantly higher in spelt grain harvested at the fully ripe stage than in green spelt grain. A similar relationship was found for linoleic acid. In green spelt grain, the total content of oleic acid and $\alpha$-linolenic acid was higher compared to that in spelt grain harvested at the fully ripe stage. The content of saturated fatty acids (SFA) as well as polyunsaturated fatty acids (PUFA) was significantly lower in unripe spelt grain than in the ripe spelt grain, but the content of monounsaturated fatty acids (MUFA) was significantly higher in grain harvested at the milk dough stage than in grain obtained at fully ripe stage. Spelt grain harvested at the fully ripe stage was characterized by a significantly higher content of $\omega 6$ acids, whereas green spelt grain contained a higher amount of $\omega 3$ and $\omega 9$ acids. Interestingly, more favorable ratio of $\omega 6$ to $\omega 3$ (7.92/1) was found in the case of green spelt grain compared to ripe grain (19.04/1). In Western diets, the ratio of $\omega 6 / \omega 3$ is about 15/1-16.7/1 [33]. This is associated with too low $\omega-3$ fatty acids content and an excessive amount of $\omega-6$ fatty acids in human diets. Such situation may contribute to the pathogenesis of many diseases, in particular cancer and cardiovascular diseases.

Kraska et al. [20] did not observe any variation in the content of the fatty acids 16:0, 18:0, 18:1 c9 and 18:2 c9 c12 in the spelt wheat cultivars investigated in their study. However, the content of the $18: 3$ c9 c12 c15 fatty acid was found to be higher in the green grain of all spelt wheat cultivars than in ripe grain. Furthermore, the authors found a slightly higher content of SFA and PUFA in spelt grain obtained at the fully ripe stage, while a higher content of MUFA was found in green grain. In their study comparing more than 40 spelt wheat genotypes, Escarnot et al. [10] reported a slightly higher content of 16:0 (from $16.7 \%$ to $18.5 \% \mathrm{DM}$ ) compared to that observed in the present study, as well as a similar content of $18: 0$ (from $0.7 \%$ to $1.4 \% \mathrm{DM}$ ) and $18: 2 \mathrm{c} 9 \mathrm{c} 12$ (from $55.0 \%$ to $63.2 \% \mathrm{DM}$ ).

Although the control bread and bread enriched with spelt grain harvested at the milk dough stage showed a similar lipids content, the composition of fatty acids significantly varied among them (Table 8).

The use of green spelt grain at the proportions of $4 \%, 8 \%$ and $12 \%$ resulted in a significant reduction in the content of stearic, oleic, and $\alpha$-linolenic acid in enriched bread compared to the control bread. The same relationship was found for the content of MUFA, and $\omega 3$, and $\omega 9$ acids. The ratio of $\omega 6 / \omega 3$ in bread enriched with green spelt grain (14.42/1-15.76/1) was higher than in control bread (12.55/1), what may slightly reduce the nutritional value of such products. Bread with $4 \%$ unripe spelt grain was characterized by a significantly higher content of palmitic acid and SFA than all other tested breads. However, it had the lowest content of oleic acid, MUFA, and $\omega 3$ acids. Among all the bread 
samples evaluated, those enriched with $8 \%$ green spelt grain showed the highest content of linoleic acid and PUFA. On the other hand, they contained the least amount of palmitic and stearic acid, as well as the lowest SFA. In the case of BGS12, the lowest content of $\alpha$-linolenic acid was found in comparison to all other tested bread samples. Moreover, it contained a significantly lower content of $\omega 3$ acids than CB and BGS4.

Table 8. Lipid content [\%], the fatty acids profile [\%] and overall acceptability in control bread and bread enriched with green spelt grain.

\begin{tabular}{ccccc}
\hline \multirow{2}{*}{$\begin{array}{c}\text { Lipid Content, Fatty Acids Profile } \\
\text { and Overall Acceptability }\end{array}$} & \multicolumn{4}{c}{ Type of Bread } \\
\cline { 2 - 5 } & CB $^{\mathbf{1}}$ & BGS4 & BGS8 & BGS12 \\
\hline Lipid content & $2.93 \pm 0.15 \mathrm{a}$ & $2.86 \pm 0.14 \mathrm{a}$ & $2.88 \pm 0.14 \mathrm{a}$ & $2.80 \pm 0.14 \mathrm{a}$ \\
$16: 0$ & $18.11 \pm 0.91 \mathrm{a}$ & $19.09 \pm 0.57 \mathrm{~b}$ & $17.95 \pm 0.90 \mathrm{a}$ & $18.07 \pm 0.54 \mathrm{a}$ \\
$18: 0$ & $1.52 \pm 0.05 \mathrm{~d}$ & $1.46 \pm 0.07 \mathrm{~b}$ & $1.42 \pm 0.04 \mathrm{a}$ & $1.50 \pm 0.08 \mathrm{c}$ \\
$18: 1 \mathrm{c} 9$ & $29.71 \pm 1.19 \mathrm{c}$ & $26.33 \pm 1.32 \mathrm{a}$ & $27.16 \pm 1.09 \mathrm{~b}$ & $27.23 \pm 1.36 \mathrm{~b}$ \\
$18: 2 \mathrm{c} 9, \mathrm{c} 12$ & $43.22 \pm 2.16 \mathrm{a}$ & $45.84 \pm 1.83 \mathrm{~b}$ & $46.53 \pm 2.33 \mathrm{~d}$ & $46.15 \pm 1.85 \mathrm{c}$ \\
$18: 3 \mathrm{c} 9, \mathrm{c} 12, \mathrm{c} 15$ & $3.45 \pm 0.07 \mathrm{~d}$ & $3.19 \pm 0.06 \mathrm{c}$ & $3.10 \pm 0.06 \mathrm{~b}$ & $2.95 \pm 0.06 \mathrm{a}$ \\
SFA & $21.23 \pm 0.85 \mathrm{~b}$ & $22.20 \pm 1.11 \mathrm{c}$ & $20.89 \pm 0.84 \mathrm{a}$ & $21.16 \pm 1.06 \mathrm{~b}$ \\
MUFA & $31.87 \pm 1.59 \mathrm{c}$ & $28.46 \pm 0.85 \mathrm{a}$ & $29.20 \pm 1.46 \mathrm{~b}$ & $29.27 \pm 0.88 \mathrm{~b}$ \\
PUFA & $46.74 \pm 2.34 \mathrm{a}$ & $49.20 \pm 2.46 \mathrm{~b}$ & $49.84 \pm 2.49 \mathrm{~d}$ & $49.44 \pm 2.47 \mathrm{c}$ \\
$\omega 3$ & $3.45 \pm 0.15 \mathrm{c}$ & $3.19 \pm 0.16 \mathrm{~b}$ & $3.10 \pm 0.12 \mathrm{~b}$ & $2.95 \pm 0.15 \mathrm{a}$ \\
$\omega 6$ & $43.30 \pm 1.30 \mathrm{a}$ & $46.01 \pm 1.84 \mathrm{~b}$ & $46.75 \pm 1.40 \mathrm{c}$ & $46.49 \pm 1.86 \mathrm{c}$ \\
$\omega 9$ & $30.64 \pm 1.53 \mathrm{c}$ & $27.22 \pm 1.35 \mathrm{a}$ & $28.03 \pm 1.40 \mathrm{~b}$ & $28.08 \pm 1.40 \mathrm{~b}$ \\
$\omega$ 6/ $\omega 3$ & $12.55 \pm 0.38 \mathrm{a}$ & $14.42 \pm 0.57 \mathrm{~b}$ & $15.08 \pm 0,75 \mathrm{bc}$ & $15.76 \pm 0,78 \mathrm{c}$ \\
Overall acceptability & $6.5 \pm 0.45 \mathrm{a}$ & $6.8 \pm 0.45 \mathrm{ab}$ & $7.1 \pm 0.45 \mathrm{~b}$ & $7.5 \pm 0.45 \mathrm{~b}$ \\
\hline
\end{tabular}

\footnotetext{
${ }^{1}$ CB-control bread; BGS4-bread enriched with $4 \%$ of green spelt grain; BGS8-bread enriched with $8 \%$ of green spelt grain; BGS12—-bread enriched with 12\% of green spelt grain; 16:0—palmitic acid; 18:0— stearic acid; 18:1 c9-oleic acid; 18:2 c9, c12-linoleic acid; 18:3 c9, c12, c15- $\alpha$ linolenic acid; SFA-Saturated fatty acid; MUFA-Monounsaturated fatty acid; PUFA-Polyunsaturated fatty acid; $\omega$ 3-omega-3 PUFA; $\omega$ 6-omega- 6 PUFA; $\omega$ 9-omega-9 PUFA; Different letter $(a, b, c, d)$ in the same raw indicate statistically significant difference between means $(p \leq 0.05)$.
}

The results of preliminary sensory evaluation of breads (Table 8) indicate that bread enriched with spelt grain showed similar notes as control bread. Each kind of bread was tasty and had a specific pleasant aroma. The use of green spelt grain at the proportions of $8 \%$ and $12 \%$ resulted in higher scores for crumb appearance and texture and thus general desirability of these bread was slightly higher but significantly higher in comparison with control bread.

\section{Conclusions}

In the present study, freeze-dried green grain of spelt is proposed as an additive for preparing wholemeal spelt bread, with improved nutritional value.

The results of the study showed that ripe spelt grain had a significantly higher content of palmitic, stearic, and linoleic acid, PUFA, and $\omega 6$ acids compared to grain harvested at the milk dough stage. However, green spelt grain was characterized by a significantly higher content of $\mathrm{P}, \mathrm{Mg} \mathrm{Ca}$, and $\mathrm{Zn}$. Additionally, it contained significantly more amino acids (Asp, Thr, Ser, Gly, Ala, Cys, Val, Met, Ile, Leu, Phe, Lys, Trp), lipids, oleic acid, and $\alpha$-linolenic acid, as well as MUFA, $\omega 3$ and $\omega 9$ acids. This clearly indicates that green spelt grain is a valuable source of nutrients and can therefore be successfully included in the human diet.

Green spelt grain used as an additive had a beneficial effect on the chemical composition of the bread samples, however the $\omega 6 / \omega 3$ ratio in bread enriched with green spelt grain was slightly less favorable than in control bread. Bread enriched with green grain at an amount of $4 \%$ contained significantly more Mn, amino acids (Glu, Ala, Cys, Val, Leu, Phe, His, Lys, Arg, Trp), and palmitic and linoleic acids, as well as PUFA and $\omega 6$ acids, compared to control bread prepared without green grain. Increasing the percentage of the green spelt grain in spelt flour from $4 \%$ to $8 \%$ contributed to a significant increase in the content of P, B, Asp, Ser, and Trp, as well as fatty acids (oleic and linoleic 
acids, MUFA, PUFA, $\omega 6$ and $\omega 9$ acids). On the other hand, the content of most amino acids (Glu, Pro, Cys, Val, Ile, Leu, Phe, His, Lys, Arg), palmitic, stearic, and $\alpha$-linolenic acids, and SFA decreased with the addition of $8 \%$ of green grain compared to bread with $4 \%$ proportion of unripe grain. Among all the products tested, bread with $12 \%$ of green spelt grain was found to be the richest in amino acids (except for Pro, Cyst and Met). Moreover, the addition of green spelt grain into wheat flour at the proportions of $8 \%$ and $12 \%$ resulted in higher scores for overall acceptability of bread.

In conclusion, green spelt grain can serve as an excellent additive to improve the dietary value of bakery products and, thus, it is possible to supplement nutrients that are deficient in the diet through the consumption of bread enriched with freeze-dried green spelt grains.

Author Contributions: Conceptualization, P.K., D.D. and S.A.; validation, E.K.-P.; formal analysis, D.D.; investigation, P.K., S.A., U.G.-D. and D.D.; writing-original draft preparation, P.K., S.A. and D.D.; analyzed data P.K. and S.A.; writing-review and editing, P.K., S.A. and D.D. All authors have read and agreed to the published version of the manuscript.

Funding: This research was funded by Ministry of Agriculture and Rural Development; Ministry of Science and Higher Education, Poland.

Conflicts of Interest: The authors declare no conflict of interest. The funders had no role in the design of the study; in the collection, analyses, or interpretation of data; in the writing of the manuscript, or in the decision to publish the results.

\section{References}

1. Dziki, D.; Różyło, R.; Gawlik-Dziki, U.; Świeca, M. Current trends in the enhancement of antioxidant activity of wheat bread by the addition of plant materials rich in phenolic compounds. Trends Food Sci. Technol. 2014, 40, 48-61. [CrossRef]

2. Padma, I.S.; Kiran, M.D.; Srinivasulu, N.; Anandharamakrishnan, C. Impact of wheat bran addition on the temperature-induced state transitions in dough during bread-baking process. Int. J. Food Sci. Technol. 2017, 53, 404-411.

3. Rasane, P.; Jha, A.; Sabikhi, L.; Kumar, A.; Unnikrishnan, V.S. Nutritional advantages of oats and opportunities for its processing as value added foods-A review. J. Food Sci. Technol. 2013, 52, 662-675. [CrossRef] [PubMed]

4. Marti, A.; Cardone, G.; Ambrogina, M.A.; Casiraghi, C. Flour from sprouted wheat as a new ingredient in bread-making. LWT-Food Sci. Technol. 2018, 89, 237-243. [CrossRef]

5. Zabetakis, I.; Zordan, R.; Tsoupras, A. The Impact of Nutrition and Statins on Cardiovascular Diseases; Academic Press, Imprint of Elsevier: Cambridge, MA, USA, 2019; p. 348.

6. Samar, M.M.; Ferro Fontan, C.; Resnik, S.; Pacin, A.; Castillo, M. Distribution of deoxynivalenol in wheat, wheat flour, bran, and gluten, and variability associated with the test procedure. J. AOAC Int. 2003, 86, 551-556. [CrossRef]

7. Mousia, Z.; Edherly, S.; Pandiella, S.S.; Webb, C. Effect of wheat pearling on flour quality. Food Res. Int. 2004, 37, 449-459. [CrossRef]

8. Moudrý, J.; Konvalina, P.; Stehno, Z.; Capouchová, I.; Moudrý, J., Jr. Ancient wheat species can extend biodiversity of cultivated crops. Sci. Res. Essays 2011, 6, 4273-4280.

9. Campbell, K.G. Spelt: Agronomy, genetics, and breeding. Plant Breed. Rev. 1997, 15, 188-213.

10. Escarnot, E.; Jacquemin, J.M.; Agneessens, R.; Paquot, M. Comparative study of the content and profiles of macronutrients in spelt and wheat (a review). BASE 2012, 16, 243-256.

11. Jablonskytè-Raščè, D.; Maikšteniene, S.; Mankevičiene, A. Evaluation of productivity and quality of common wheat (Triticum aestivum L.) and spelt (Triticum spelta L.) in relation to nutrition conditions. Zemdirbyste 2013, 100, 45-55. [CrossRef]

12. Stępień, A.; Wojtkowiak, K.; Orzech, K.; Wiktorski, A. Nutritional and technological characteristics of common and spelt wheats are affected by mineral fertilizer and organic stimulator Nano-Groß. Acta Sci. Pol. Agric. 2016, 15, 49-63.

13. Kraska, P.; Andruszczak, S.; Kwiecińska-Poppe, E.; Pałys, E. Effect of chemical crop protection on the content of some elements in grain of spelt wheat (Triticum aestivum ssp. spelta). J. Elem. 2013, 18, 79-90. [CrossRef] 
14. Andruszczak, S. Spelt wheat grain yield and nutritional value response to sowing rate and nitrogen fertilization. JAPS J. Anim. Plant Sci. 2018, 28, 1476-1484.

15. Gawlik-Dziki, U.; Świeca, M.; Dziki, D. Comparison of phenolic acids profile and antioxidant potential of six varieties of spelt (Triticum spelta L.). J. Agric. Food Chem. 2012, 60, 4603-4612. [CrossRef] [PubMed]

16. Świeca, M.; Dziki, D.; Gawlik-Dziki, U.; Różyło, R.; Andruszczak, S.; Kraska, P.; Kowalczyk, D.; Pałys, E.; Baraniak, B. Grinding and nutritional properties of six spelt (Triticum aestivum ssp. spelta L.) cultivars. Cereal Chem. 2014, 91, 247-254. [CrossRef]

17. Brandolini, A.; Hidalgo, A.; Gabriele, S.; Heun, M. Chemical composition of wild and feral diploid wheats and their bearing on domesticated wheats. J. Cereal Sci. 2015, 63, 122-127. [CrossRef]

18. Biskup, I.; Gajcy, M.; Fecka, I. The potential role of selected bioactive compounds from spelt and common wheat in glycemic control. Adv. Clin. Exp. Med. 2017, 26, 1013-1019. [CrossRef]

19. Abdel-Aal, E.S.M.; Wood, P. Specialty Grains for Food and Feed; American Association of Cereal Chemists: Saint Paul, MN, USA, 2004; p. 413.

20. Kraska, P.; Andruszczak, S.; Dziki, D.; Stocki, M.; Stocka, N.; Kwiecińska-Poppe, E.; Różyło, K.; Gierasimiuk, P. Green grain of spelt (Triticum aestivum ssp. spelta) harvested at the stage of milk-dough as a rich source of valuable nutrients. Emir. J. Food Agric. 2019, 31, 263-270. [CrossRef]

21. Ruibal-Mendieta, N.L.; Delacroix, D.L.; Mignolet, E.; Pycke, J.M.; Marques, C.; Rozenberg, R.; Petitjean, G.; Habib-Jiwan, J.L.; Meurens, M.; Quetin-Leclercq, J.; et al. Spelt (Triticum aestivum ssp. spelta) as a source of breadmaking flours and bran naturally enriched in oleic acid and minerals but not phytic acid. J. Agric. Food Chem. 2005, 53, 2751-2759. [CrossRef]

22. Biernacka, B.; Dziki, D.; Gawlik-Dziki, U.; Różyło, R.; Siastała, M. Physical, sensorial, and antioxidant properties of common wheat pasta enriched with carob fiber. LWT-Food Sci. Technol. 2017, 77, 186-192. [CrossRef]

23. Romankiewicz, D.; Hassoon, W.H.; Cacak-Pietrzak, G.; Sobczyk, M.; Wirkowska-Wojdyła, M.; Ceglińska, A.; Dziki, D. The effect of chia seeds (Salvia hispanica L.) addition on quality and nutritional value of wheat bread. J. Food Qual. 2017, 2017, 7352631. [CrossRef]

24. Ostrowska, A.; Gawliński, A.; Szczubiałka, Z. Metody analizy i oceny właściwości gleb i roślin; Institute of Plant Protection: Warsaw, Poland, 1991; p. 334.

25. Iglesias-Puig, E.; Monedero, V.; Haros, C.M. Bread with whole quinoa flour and bifidobacterial phytases increases dietary mineral intake and bioavailability. LWT-Food Sci. Technol. 2015, 60, 71-77. [CrossRef]

26. Andruszczak, S. Reaction of winter spelt cultivars to reduced tillage system and chemical plant protection. Zemdirbyste 2017, 104, 15-22. [CrossRef]

27. Wojtkowiak, K.; Stępień, A. Nutritive value of spelt (Triticum aestivum spp. spelta L.) as influenced by the foliar application of copper, zinc and manganese. Zemdirbyste 2015, 102, 389-396. [CrossRef]

28. Wanic, M.; Denert, M.; Treder, K. Effect of forecrops on the yield and quality of common wheat and spelt wheat grain. J. Elem. 2019, 1, 369-383. [CrossRef]

29. Litwinek, D.; Gambuś, H.; Buksa, K.; Makarewicz, M.; Zięć, G.; Gambuś, F.; Kowalczyk, M.; Boreczek, J. Quality and aging of bread from wholemeal common wheat and spelt flours, and from wholemeal rye flour. Żywność Nauka Technologia Jakość 2018, 25, 50-72. [CrossRef]

30. Grembecka, M.; Kusiuk, A.; Szefer, P. Content of magnesium, phosphorus, zinc and iron in different kinds of bread. Bromat. Chem. Toksykol. 2007, 4, 319-323.

31. Waga, J.; Węgrzyn, S.; Boros, D.; Cygankiewicz, A. Utilization of spelt wheat (Triticum aestivum ssp. spelta) for improving the nutritional qualities of common wheat (Triticum aestivum ssp. vulgare). Biuletyn-Instytutu Hodowli i Aklimatyzacji Roslin 2002, 221, 3-16.

32. Sulewska, H.; Koziara, W.; Panasiewicz, K.; Ptaszyńska, G.; Mrozowska, M. Chemical composition of grain and protein yield of spelt cultivars depending on selected agrotechnical factors. J. Res. Appl. Agric. Eng. 2008, 53, 92-95.

33. Simopoulos, A.P. The importance of the omega-6/omega-3 fatty acid ratio in cardiovascular disease and other chronic diseases. Exp. Biol. Med. 2008, 233, 674-688. [CrossRef]

(C) 2020 by the authors. Licensee MDPI, Basel, Switzerland. This article is an open access article distributed under the terms and conditions of the Creative Commons Attribution (CC BY) license (http://creativecommons.org/licenses/by/4.0/). 